\title{
Letter to the editor: Vitamin D receptor gene BsmI polymorphism with type 2 diabetes mellitus
}

\author{
Beuy Joob ${ }^{1}$, Viroj Wiwanitkit ${ }^{2}$
}

1. Sanitation1 Medical Academic Center, Bangkok Thailand

2. Honorary professor, Dr DY Patil University, Pune, India; visiting professor, Hainan Medical University, Haikou, China

DOI: https://dx.doi.org/10.4314/ahs.v20i1.61

Cite as: Joob B, Wiwanitkit V. Letter to the editor: Vitamin D receptor gene BsmI polymorphism with type 2 diabetes mellitus. Afri Health Sci. 2020;20(1):543-4. https://dx.doi.org/10.4314/abs.v20i1.61

Dear Editor, we read the publication on "Association of Vitamin D receptor (VDR) gene BsmI polymorphism with type 2 diabetes mellitus (T2DM) in Pakistani population" with a great interest. Fatma and Abdul noted that "The current study did not provide evidence for the association of VDR gene BsmI polymorphism with T2DM in Pakistani population ${ }^{1}$." In fact, the effect of genetic polymorphism on T2DM is widely discussed in the literature. The lack of association in the report by Fatma and Abdul might be due to several reasons. Focusing on the effect of single VDR gene BsmI (rs1544410 A>G) polymorphism, the effect might be explained by the molecular change. Based on the previously published articles ${ }^{2-3}$, the molecular weight change due to gene BsmI (rs1544410 $A>G$ ) polymorphism, focusing at single mutation $A>G$, is equal to $16 \mathrm{~g} / \mathrm{Mol}$ (from 135.13 to $151.13 \mathrm{~g} / \mathrm{Mol}$ ). This change can further affect the final phenotypic expression. In the present report, Fatma and Abdul studied on single polymorphism, there might be possible effects of other genetic polymorphisms that are associated with T2DM such as Apolipoprotein E andmethylenetetrahydrofolate reductase gene polymorphisms ${ }^{4-5}$. A good case - control study to cover the possible genetic polymorphisms that might affect T2DM is necessary for final conclusion.

\section{Conflict of interest}

None.

\section{References}

1. Fatma H, Abdul SN. Association of Vitamin D receptor gene BsmI polymorphism with type 2 diabetes mellitus in Pakistani population. Afr Health Sci. 2019 Jun;19(2):2164-2171.

2. Joob S, Guran M. Letter to editor: Endothelial nitric oxide synthase Glu 298 Asp (G894T) and risk factors for coronary heart disease. Adv Lab Med Int. 2019; 9: 25 - 27. 3. Joob S, Guran M. Letter to editor: G12V and G12C mutations in the gene KRAS and association with prognosis in primary colorectal cancer. Adv Lab Med Int. 2019; 9: $28-30$.

4. Dong Y, Li W, Wang T, Miao J, Li T, Zhou Y. Effects of methylenetetrahydrofolate reductase gene polymorphism and long-term exposure to organophosphorus pesticides on type 2 diabetes mellitus. Wei Sheng Yan Jiu. 2019 Jul;48(4):621-627.

5. Liu S, Liu J, Weng R, Gu X, Zhong Z. Apolipoprotein $\mathrm{E}$ gene polymorphism and the risk of cardiovascular disease and type 2 diabetes. BMC Cardiovasc Disord. 2019 Sep 14;19(1):213.

\section{Corresponding author: \\ Beuy Joob, Sanitation1 Medical Academic \\ Center, Bangkok Thailand, Email: beuyjoob@hotmail.com}




\section{Reply to letter: Association of Vitamin D receptor gene BsmI polymorphism with type 2 diabetes mellitus}

Fatma Hussain1*, Naila Abdul Sattar 2

1. Department of Biochemistry, Faculty of Sciences, University of Agriculture, Faisalabad,Pakistan. Email: fatmauaf@yahoo.com

2. Department of Biochemistry, Government College for Women University, Faisalabad, Pakistan. Email: uaf_naila_sattar@yahoo.com

Dear Editor: We thank Beuy Joob and Viroj Wiwanitkit for their letter regarding our published manuscript: "Association of Vitamin D receptor gene BsmI polymorphism with type 2 diabetes mellitus in Pakistani population"1.Their letter has two main points:

One: Focusing on the effect of single VDR gene BsmI (rs1544410 A>G) polymorphism, the effect might be explained by the change in molecular weight.This is a good suggestion. It can be an extension of current work for future investigations.However, it was not part of the research proposal approved by the university supervisory committee. The foreign evaluators for the $\mathrm{PhD}$ thesis also gave positive comments.
Two: The possible effects of other genetic polymorphisms associated with T2DM should have been studied. The research work presented by Fatma and Abdul is part of a PhD dissertation. Four SNPs were studied but data of only one SNP was presented in the article.

\section{Reference}

1. Fatma H, Abdul SN. Association of Vitamin D receptor gene BsmI polymorphism with type 2 diabetes mellitus in Pakistani population. Afr Health Sci. 2019 Jun;19(2):2164-2171. 